\title{
Long-term Field Monitoring of the Novel Seamless Abutment Bridge under Temperature Effect
}

\author{
Yibin Zhao ${ }^{1}$, Jiejun Wang ${ }^{1}$, Xuefang Zhan ${ }^{1, *}$ and Bigang Tang ${ }^{2}$ \\ ${ }^{1}$ School of Civil Engineering, Central South University of Forestry and Technology, Changsha 410004, Hunan Province, China \\ ${ }^{2}$ Hunan Communications Research Institute Co., LTD., Changsha 410082, Hunan Province, China
}

Received 14 September 2021; Accepted 22 November 2021

\begin{abstract}
Temperature acting on the structure can directly influence the mechanical property of a jointless bridg, so the length of jointless bridge is limited. This study proposed the novel seamless abutment bridge (SAB) as a supplement to expand the length of a jointless bridge and performed long-term field monitoring of the instrumented bridge Dayankeng Bridge to investigate the performance of the SAB under temperature effect. The finite element model was established, and analysis was performed to observe the mechanical performance of the bridge under temperature decrease. The parameters analysis was also carried out by considering the different materials of the base. Results demonstrate that structure temperatures closely track measured ambient temperatures, and the time-lag between ambient and structure temperatures is small because of the thermal inertia of the concrete structure. Thus, ambient temperature can be employed to represent structure temperature, the earth pressures around the sleeper beam increase with the increase of temperature difference, and the pressure is greater than one that is closer to the abutment. Approximately $20 \%-40 \%$ thermal displacement is absorbed by the structure behind the seamless abutment (such as pavement). With the increase of temperature difference, more deformation is absorbed by the pavement. The influence of the additional force acting on the girder induced by accessory structures behind the abutment is small. Furthermore, the impact of different materials of the base on the mechanical performance of SAB is minimal. Some suggestions can be provided to optimize the design of the SAB.
\end{abstract}

Keywords: Seamless Abutment Bridge, Long-Term Experimental Study, Temperature Effect, Numerical Study, Material of Base

\section{Introduction}

Jointless bridges are robust structures without joints. Thus, they are less vulnerable to natural and man-made hazards, while they are required minimal maintenance throughout their lifespan [1-2]. Three types of jointless bridges, integral abutment bridge (IAB), semi-integral abutment bridge (SIAB), and deck-extension bridge (DEB) [3], are proposed, as shown in Fig. 1.

In recent years, the design and construction of an IAB and a SIAB were introduced in the USA widely, and more than 16900 IAB or SIAB were constructed (approximately $2.9 \%$ of the total number of bridges in the USA [4-5]). The same applies to Western Europe, Japan, and Australia. In the existing literature, the emphasis on IAB and SIAB mainly includes the soil-structure interaction [6], the seismic performance of IAB and SIAB [7], and long-term field studies [8-9], and some standards have been published [1011]. No matter where expansion joints are located, problems continue to exist at the abutment or at the end of the approach slab. Furthermore, the concrete piles are widely used in China with large stiffness. Sufficient flexibility cannot be provided to absorb the temperature deformation of the superstructure. Thus, IAB or SIAB is not extensively used in China.
DEB is widely applied in some provinces of China. So far, more than 23 bridges of this type has opened to traffic (approximately $57.5 \%$ of the total jointless bridges in China), and all of them have performed well [5]. However, this kind of bridge is only suitable for short and medium-span bridges whose total length is less than $100 \mathrm{~m}$ [12-13]. Half of such bridges are less than $50 \mathrm{~m}$ in total length.

The novel seamless abutment bridge (SAB) is proposed herein (as shown in Fig. 2) to extend the range of application of DEB. Conventional expansion devices installed at the end of the bridge against the abutments are eliminated. Thus, the damage of vehicle jump can be solved. When the temperature changes, the bridge shrinks or expands, and the partial temperature deformation of the main girder is transferred to the continuous reinforcement concrete pavement (CRCP) and absorbed by micro cracks [14-15]. A new type of pavement using strain-hardening cementitious composite (SHCC) material is proposed [16]. However, in the present studies, numerical calculation and library study are mainly investigated.

Based on the above analysis, a long-term field study was carried out to obtain responses concerning thermal loading for the instrumented SAB (Dayankeng Bridge). Meanwhile, the finite element (FE) analysis was done using ANSYS. Some suggestions are provided for the design and calculation of the SAB. 


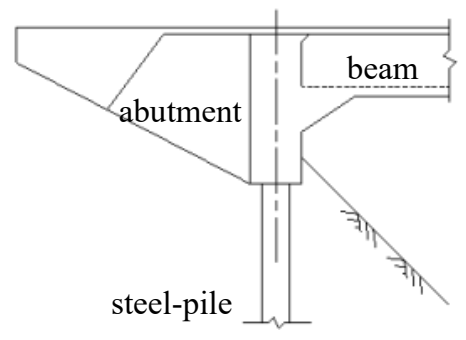

(a)

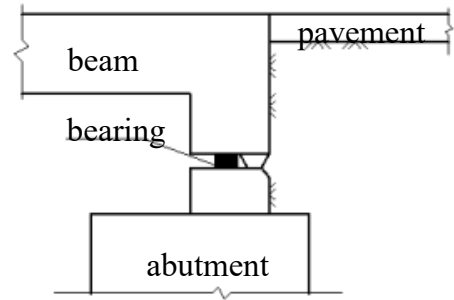

(b)

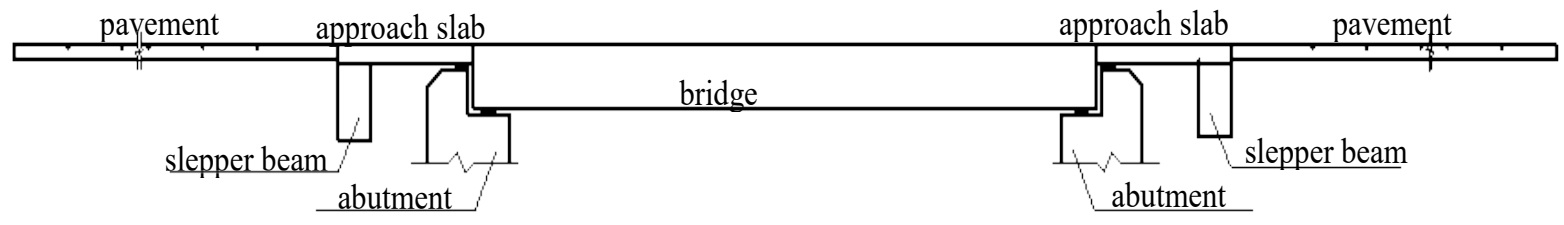

(c)

Fig.1. Types of jointless bridge. (a) Integral abutment. (b) Semi-integral abutment. (c) Deck-extension bridge

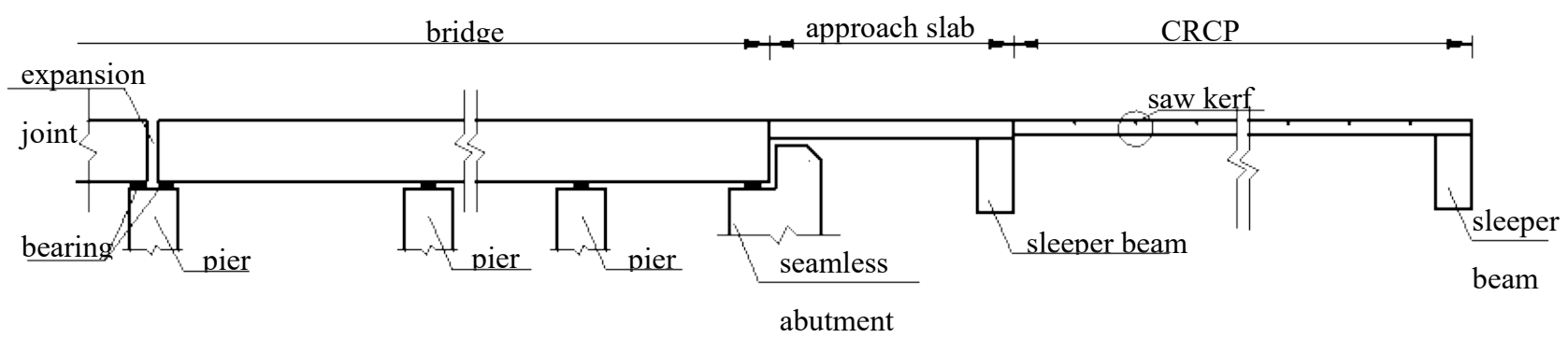

Fig.2. Novel SAB

\section{State of the art}

FE analysis has become increasingly popular. Abdal-Fattah [17] presented the finite-element study of the behavior of the integral frame abutment bridges under alternate cycles of expansion and contraction of the bridge caused by seasonal temperature variations. However, the changing soil stiffness caused by the repeated compaction of the backfill under cyclic temperature was not considered. The parametric study was performed and validated to a field monitored concrete IAB using a three-dimension FE model, and the soil stiffness around the pile was found to have more impact than the pile orientation. The maximum stress occurred at the middle segment of the pile. However, the results of the cracks' development and width were not acquired [18]. The models were established to study the behavior of the pile considering different types of soil by using Midas Civil, and the performance of components was found mainly depended on the stiffness of the foundation soil. However, the difference between active and passive earth pressure when temperature changes were not considered [19].

Scale model experiments were developed to study the abutment-soil interactions at three different magnitudes of cyclic translational movements $(0.5,1$, and $2 \mathrm{~mm})$. The test results show that the number of loading cycles had an important effect on the escalation of lateral earth pressure and soil deformation of the retained soil, and the maximum passive pressure resided at the bottom of the abutment. However, the stress profile does not correspond to the numerical calculation results well [20-21]. The placement of geogrids within the backfill, such as the expanded polystyrene (EPS) foam, was proposed to reduce lateral earth pressure. The lateral earth pressure and backfill settlement could be minimized by combining the EPS foam and geogrids. However, the mitigation effects by the EPS foam were limited because of its slight thickness and relatively high elastic modulus proposed [22-23].

The first jointless bridge in Korea had been monitored for 13 months, and the relationship curves between temperature change and earth pressure were fitted. However, given the limited number of pressure cells (only four pressure cells), the difference between measurement and the fitted results was noticeable [24]. The long-term monitoring for jointless bridges was carried out by Laman [8] and Huntley [25]. The data of abutment movements and earth pressures on the abutments were presented, and the relationship curves between temperature change and abutment displacement were obtained. However, the distribution of soil stress was not acquired.

A series of laboratory model tests were conducted. The seismic performance and interaction mechanism of a single pile-soil system were investigated, and the relationship curve between the seismic performance of the pile and the buried depth was acquired. However, given the small test model (the diameter of the pile was only $10 \mathrm{~cm}$ ), the mechanical properties and deformation behavior of piles of actual engineering cannot be presented well [26-28]. The influence of friction coefficient of different cushion materials on the jointless bridge was studied, but crack development was not performed [29]. The small-scale model test and theoretical analysis deduced the theoretical formulas of stress distribution and crack development of DEB; however, given the lack of long-term test data, the deteriorating structural performance was not considered [14-15]. The material of the SHCC was adopted for the pavement of jointless bridge, and the model test was carried out, but the corresponding theoretical study was not performed [16]. 
In the existing literature, the emphasis on jointless bridges mainly includes the interaction between the pile and soil. However, study about the interaction between pavement and backfill and the distribution of stress at pavement is rare. Notably, small-scale model testing and FE calculation were adopted as the main study methods. Long-term studies of jointless bridges are minimal. Thus, the stress and deformation of pavement have not been well represented.

In this study, a long-term experimental study was carried out on Dayankeng Bridge, which was reconstructed as a $\mathrm{SAB}$. The relationship between the stress distributions of the CRCP with the temperature change was investigated. Meanwhile, the FE model was established using ANSYS software, the mechanical performance of the structure under the temperature dropping was calculated, and the influence of different materials of the base on the structural performance was studied. Some suggestions were provided for the SAB design.

The remainder of this study is organized as follows. Section 3 describes basic information of Dayankeng Bridge, the long-term monitoring scheme, and the FE model. Section 4 discusses the results of monitoring and numerical analysis. Section 5 summarizes the conclusions.

\section{Methodology}

\subsection{Introduction of the instrumented bridge}

Dayankeng Bridge is located in Qingyuan, Guangdong Province, China, crossing a tributary of the Beijiang River. The layout of this bridge is shown in Fig. 3.

This bridge is $244-\mathrm{m}$ long with no skew. It is composed of 16 spans, and the span arrangement is $6 \times 16 \mathrm{~m}+5 \times 20 \mathrm{~m}$ $+3 \times 16 \mathrm{~m}$. The width of the whole bridge is $22.20 \mathrm{~m}$. Ten post-prestressed concrete constant-T-section girders were placed to composite the superstructure. The beams were set on the pier capping beam, which was supported by doublecolumn piers. Traditional ribbed slab abutments were used at the end of the bridge, with two friction piles forming the foundation.

This bridge was opened to traffic in October 2001. Serious problems have arisen, such as damage to the main girder because of overloading, the destruction of piers caused by scouring failure, and expansion devices' failure. Thus, this bridge had to be reinforced and repaired immediately in autumn 2011. Steel plates were employed to support the main beam and the pile foundation, the expansion joints at the abutment were canceled, and the abutment was reconstructed. Finally, the approach slab, $\mathrm{CRCP}$, and sleeper beams were constructed. Dayankeng Bridge was transformed into a SAB. The structure behind the seamless abutment of Dayankeng Bridge is shown in Fig. 4. Equidistant saw kerfs were formed in the CRCP with a spacing of $1 \mathrm{~m}$ to eliminate the randomness of cracking. The depth of the saw kerfs was 5-6 cm. Furthermore, the asphalt was filled in saw kerfs for waterproofing.

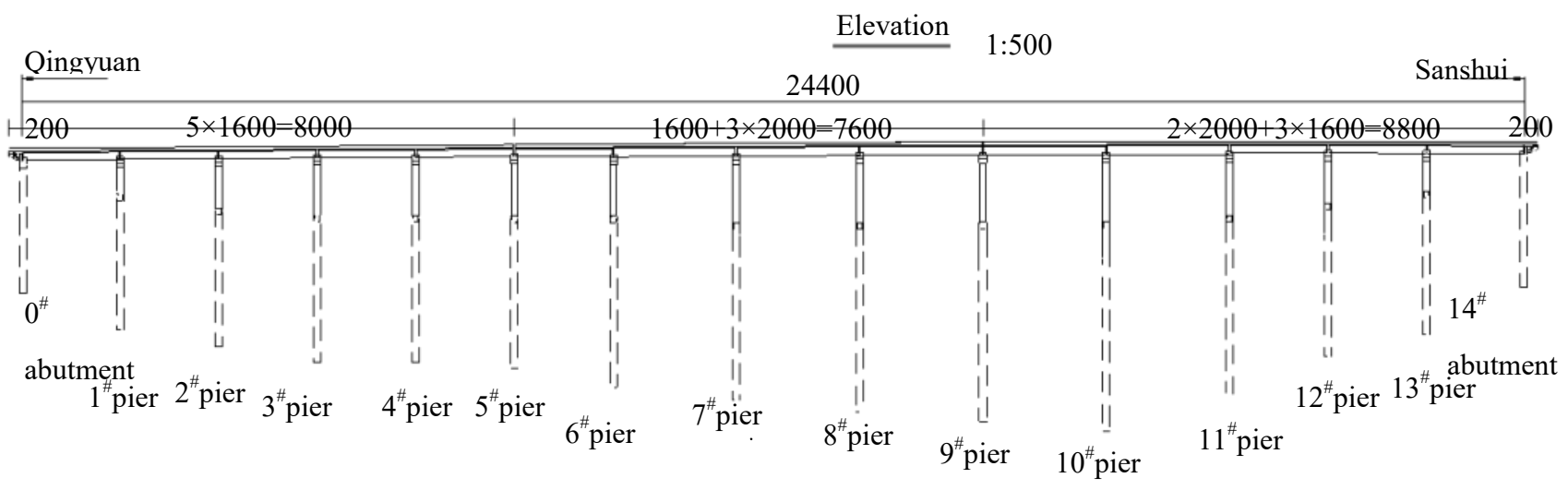

Fig.3. Layout of Dayankeng Bridge (unit: cm)

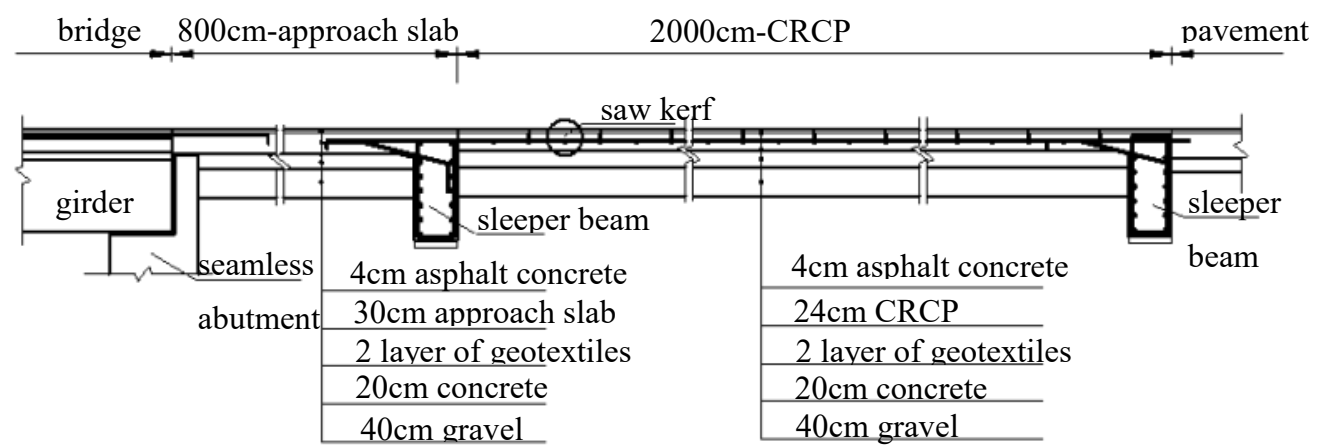

Fig.4. Detail of the seamless abutment, approach slab, and CRCP of Dayankeng Bridge (unit: $\mathrm{cm}$ )

\subsection{Long-term field study}

Dayankeng Bridge was closed on December 6, 2012 and put into operation on October 1, 2013. More than 57 measurement sensors were installed during the reconstruction process, such as thermometers, soil pressure cells, and concrete strain gauges. Long-term monitored data were obtained, and response change trends over time were established, such as the following: (1) ambient temperature and that of the concrete, (2) concrete strain in the CRCP, (3) backfill pressure, (4) girder longitudinal movement, and (5) visual inspection.

Comprehensive long-term monitoring data on the jointless bridge are rare, especially on the SAB. The continuous measurement and routine visual inspection for 
Dayankeng Bridge happen every 15 days, starting December 6, 2012. The period without vehicle traffic was selected to avoid the influence of traffic on the measurement results.

\subsection{Modeling}

ANSYS FE modeling software was employed to calculate Dayankeng Bridge. The FE model helps understanding the behavior of the SAB considering temperature dropping and respecting the base-structure interaction between pavement and different types of bases.

Dayankeng Bridge is a simply supported bridge. Thus, the characteristics of the substructure have little influence on the stress of the superstructure. Only the single T-beam between $9^{\#}$ pier-14 $4^{\#}$ pier (Fig. 3) and the structure behind the abutment were established in ANSYS modeling to reduce resource consumption and improve operation speed.

This study mainly focuses on the structure's performance behind the seamless abutment. Therefore, solid elements (element type: solid45) were adopted to simulate the structure behind the abutment and the base, and the degrees of freedom for the bottom elements of the base were constrained. Beam elements were introduced for the main girder to improve the efficiency of calculation (element type: beam189). Meanwhile, the spring elements were applied to simulate the laminated rubber bearing between the main beam and the pier (element type: combin40), and the stiffness of the spring element was calculated according to the literature [30]. The longitudinal and transverse stiffness were $3056.6 \mathrm{KN} / \mathrm{m}$, whereas the vertical stiffness was $1410888.6 \mathrm{KN} / \mathrm{m}$. The total elements of the ANSYS model were 31495, as shown in Fig. 5a.

The standard size of the element for the approach slab and the CRCP in the longitudinal direction was $0.15 \mathrm{~m}$. The width of the saw kerf was $1 \mathrm{~cm}$, with $6 \mathrm{~cm}$ in height. The size of the element around the saw kerf was appropriately smaller. The simulation of saw kerf is shown in Fig. 5b.

The important process for modeling was to simulate the friction force between the approach slab or the CRCP and the base. In this study, the surface-surface contact element (element type: Conta174) was employed. The concrete slab and pavement with more stiffness were selected as the main contact surface, whereas the base with smaller stiffness was selected as the subordinate contact surface. Thus, the contact elements are shown in Fig. 5c.

The corresponding material parameters given to the FE model are shown in Table 1. Different strength grades of concrete were adopted for the main beam, approach slab, and CRCP. Cement stabilized gravel was employed in the base, and the friction coefficient $\mu$ between the base and the approach was 2.0 [15]. The elastic-plasticity of concrete was not considered when modeling.

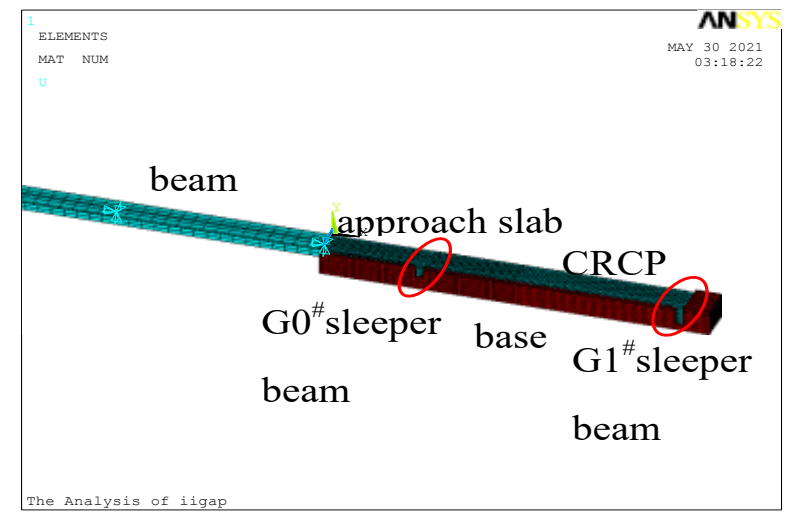

(a)

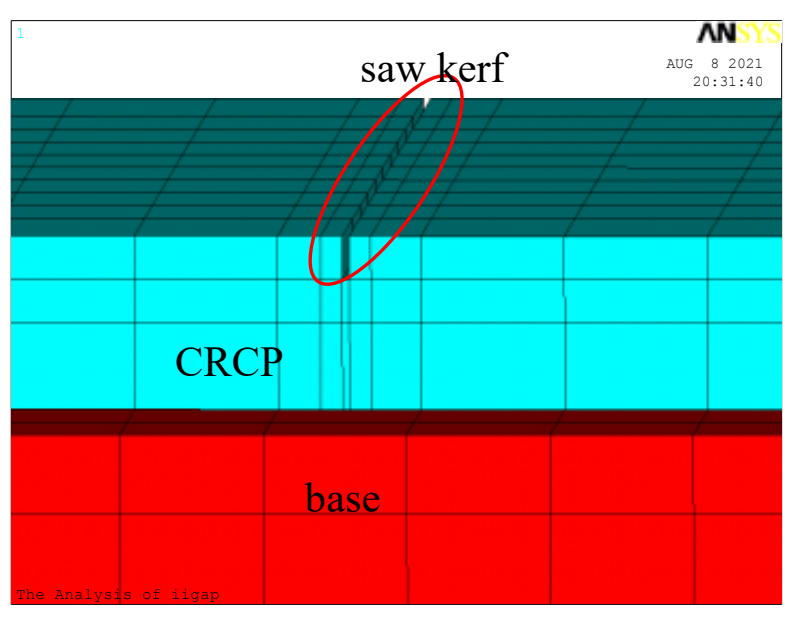

(b)

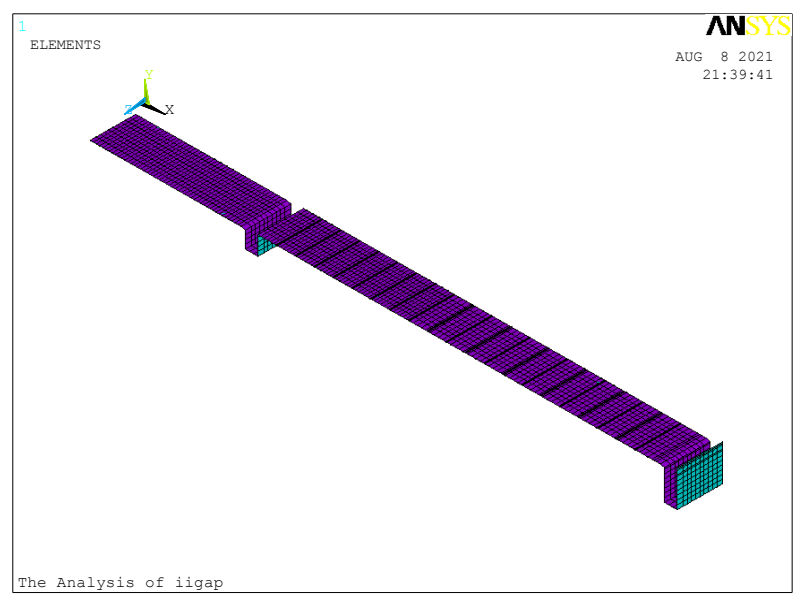

(c)

Fig. 5. FE model. (a) FE model. (b) Saw kerf. (c) Contact elements

Table 1. Material parameters

\begin{tabular}{c|c|c|c} 
Structure & Elastic modulus $(\mathbf{P a})$ & Density $\left(\mathbf{k g} / \mathbf{m}^{3}\right)$ & Poison ratio \\
Main beam & $3.25 \times 10^{10}$ & 2600 & 0.3 \\
Approach slab & $3.0 \times 10^{10}$ & 2500 & 0.2 \\
CRCP & $3.0 \times 10^{10}$ & 2500 & 0.2 \\
Base & $2.2 \times 10^{9}$ & 2300 & 0.25 \\
Sleeper beam & $3.0 \times 10^{10}$ & 2500 & 0.2
\end{tabular}

\section{Result Analysis and Discussion}

\subsection{Ambient temperature and structure temperature}

One thermometer was employed to measure the air temperature, whereas two thermometers were cast in the beam to measure the structure temperature. Superstructure thermal loading significantly influences bridge behavior, and the primary component of thermal structure loading is ambient air temperature. Ambient temperature was compared with temperatures, as presented in Fig. 6, to demonstrate this effect. The compared data used in Fig. 6 were based on an 18-month monitoring period from October 122012 to June 72014.

As shown in Fig. 6, the structure temperatures closely track the ambient temperature with a small difference. During this measurement period, the maximum ambient temperature was $36.0{ }^{\circ} \mathrm{C}$ (May 30, 2013, sunny), and the structure temperature was $35.2{ }^{\circ} \mathrm{C}$. The lowest ambient temperature was $9.1{ }^{\circ} \mathrm{C}$ (February 10, 2014, cloudy), and the structure temperature was $9.6{ }^{\circ} \mathrm{C}$. The temperature difference of structure was smaller than that of ambient temperature, 
especially during the alternating seasons. Given the $4-\mathrm{cm}$ thick asphalt pavement, the impact of drastic changes in external temperature (such as rain, snow, and solar radiation) was reduced. Thus, the CRCP was at a relatively constant temperature.

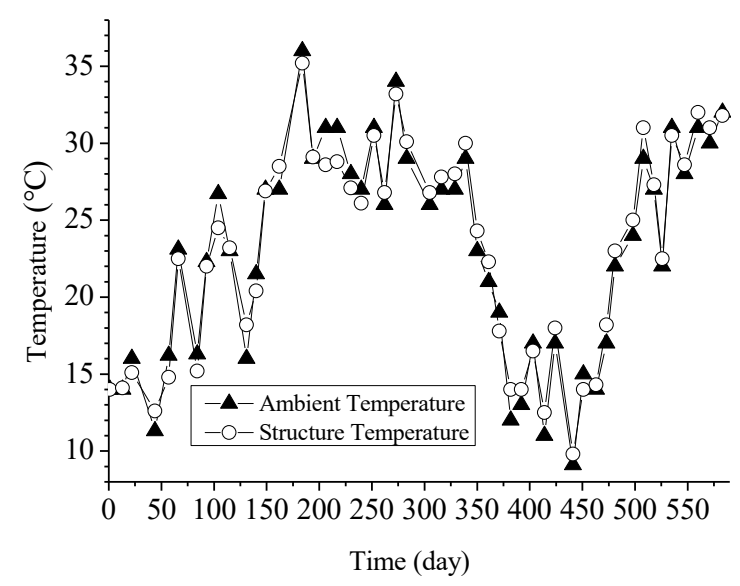

Fig. 6 . Ambient temperature and structure temperature $\left({ }^{\circ} \mathrm{C}\right)$

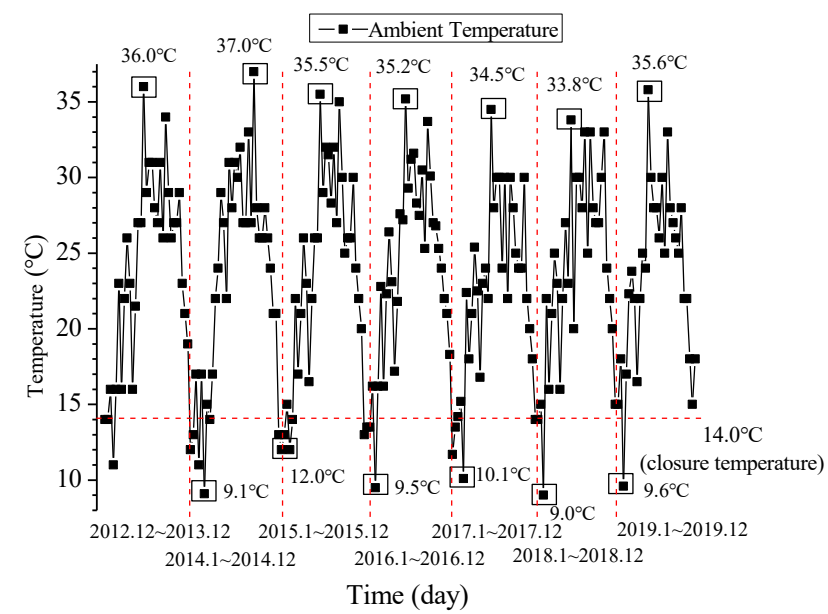

Fig. 7. Ambient temperature $\left({ }^{\circ} \mathrm{C}\right)$

Measured ambient temperature data during the whole monitoring period are given in Fig. 7. The closure temperature of the bridge was $14.0{ }^{\circ} \mathrm{C}$ on December 6, 2012, cloudy. During the 84-month (December 2012 to December 2019), the highest measured temperature was $37.0{ }^{\circ} \mathrm{C}$ (July 26, 2014, sunny), the highest temperatures measured on other days ranged from $33.8{ }^{\circ} \mathrm{C}$ to $35.6{ }^{\circ} \mathrm{C}$, and the lowest was $9.0{ }^{\circ} \mathrm{C}$ (February 11, 2018, rainy). The lowest temperatures measured on other days ranged from $9.1{ }^{\circ} \mathrm{C}$ to 12.0 ${ }^{\circ} \mathrm{C}$. The City of QingYuan is located in the subtropical monsoon region with a high annual average temperature, the maximum observed temperature change compared with closure temperature was $23{ }^{\circ} \mathrm{C}$, and the minimum was $5.0{ }^{\circ} \mathrm{C}$. The ratio of which temperature was lower than the closure temperature was only $16.4 \%$. Thus, most of the time, the air temperature was higher than the closure temperature. At the same time, the girder expanded, and the members behind the abutment were in compression. Thus, the bridge was safer than under the decreasing temperature.

\subsection{Strain}

The evident periodicity of the measured data (strain, earth pressure, and thermal movement of beam) with the change of temperature was presented for the whole measurement period of seven years. Given the limited space, this study selected the data during only one year (from December 2013 to December 2014) for subsequent analysis, including the highest temperature $\left(37.0{ }^{\circ} \mathrm{C}\right)$ and the lower temperature $\left(9.1^{\circ} \mathrm{C}\right)$.

Thirty-three strain gauges were installed in the CRCP to measure the strain at the reserved weak sections (saw kerf sections). The layout of strain gauges is represented in Fig. 8 .

Twelve strain gauges (B7-B18) were set at the bottom of the CRCP near the crash barrier at the saw kerf positions s0, s2, s4, s5, s6, s7, s9, s11, s13, s15, s17, and s19. The relationship between the strain and temperature change is shown in Fig. 9. Positive values indicate tensile strain, and negative values indicate compressive strain.

Fig. 9 shows that the temperature change significantly influenced the strains of the CRCP. When the bridge cools, the bridge shrinks and eventually pulls the slab and CRCP toward the side of the bridge. At this moment, the structures are under tension. The maximum tensile strain that occurred at saw kerf s4 (B14, $4.0 \mathrm{~m}$ from the beginning of the CRCP) was $23 \mu \varepsilon$ with the maximum temperature decrease $\left(-4.9{ }^{\circ} \mathrm{C}\right)$. The corresponding maximum tensile stress was $0.69 \mathrm{MPa}$, which was less than the tensile strength of $\mathrm{C} 30$ concrete (1.39 MPa).

As the temperature increases, the bridge expands, and the $\mathrm{CRCP}$ is subjected to compression. The maximum compressive strain (B16, $6.0 \mathrm{~m}$ from the beginning of the CRCP) was $-108 \mu \varepsilon$ with the maximum temperature increment $\left(37.0{ }^{\circ} \mathrm{C}\right)$, and the corresponding maximum compressive stress was only $3.24 \mathrm{MPa}$, which was much less than the compressive strength of $\mathrm{C} 30$ concrete $(13.8 \mathrm{MPa})$.

The data show that no crack appeared under the coldest or warmest periods because the temperature change was small (especially the temperature decrease). Thus, lower closure temperature is recommended, and common concrete can be adopted to meet standard needs [31].

Fig. 9 also shows that the measured data within this area ( $4 \mathrm{~m}$ to $7 \mathrm{~m}$ from the beginning of the CRCP) were larger than others, and the observation results were in good agreement with the calculated value of the ANSYS model. Generally speaking, the position with larger stress in the CRCP is approximately $1 / 3$ length of pavement near the abutment. Thus, a definite suggestion is proposed that the reinforcement ratio of pavement near the abutment should be increased.

Nine strain gauges were set to understand the concrete strain between the saw kerfs 84 to s7. Three strain gauges (B25-B27) were set at the middle of saw kerfs s4 to s6. Three strain gauges (B19, B21, and B23) were placed at the middle of the CRCP. The other three (B20, B22, and B24) were placed at the corresponding points on the bottom of the CRCP. The layout of stain gauges is represented by Fig. 8 . The results are shown in Fig. 10 and Fig. 11.

Fig. 10 and Fig. 11 show that the concrete strains of saw kerfs s4 to s7 were slightly greater than that at the other positions and the measured data at this area were relatively close. The results shown in Fig. 10 and Fig. 11 reveal that the strains at different heights (such as B27 and B16) of the same section were different. The strain in the middle of the height was slightly less than that of the bottom of the CRCP. No obvious trend was observed because of the paucity of measuring points. Thus, more detailed data are needed to verify the conclusion in a future study. 

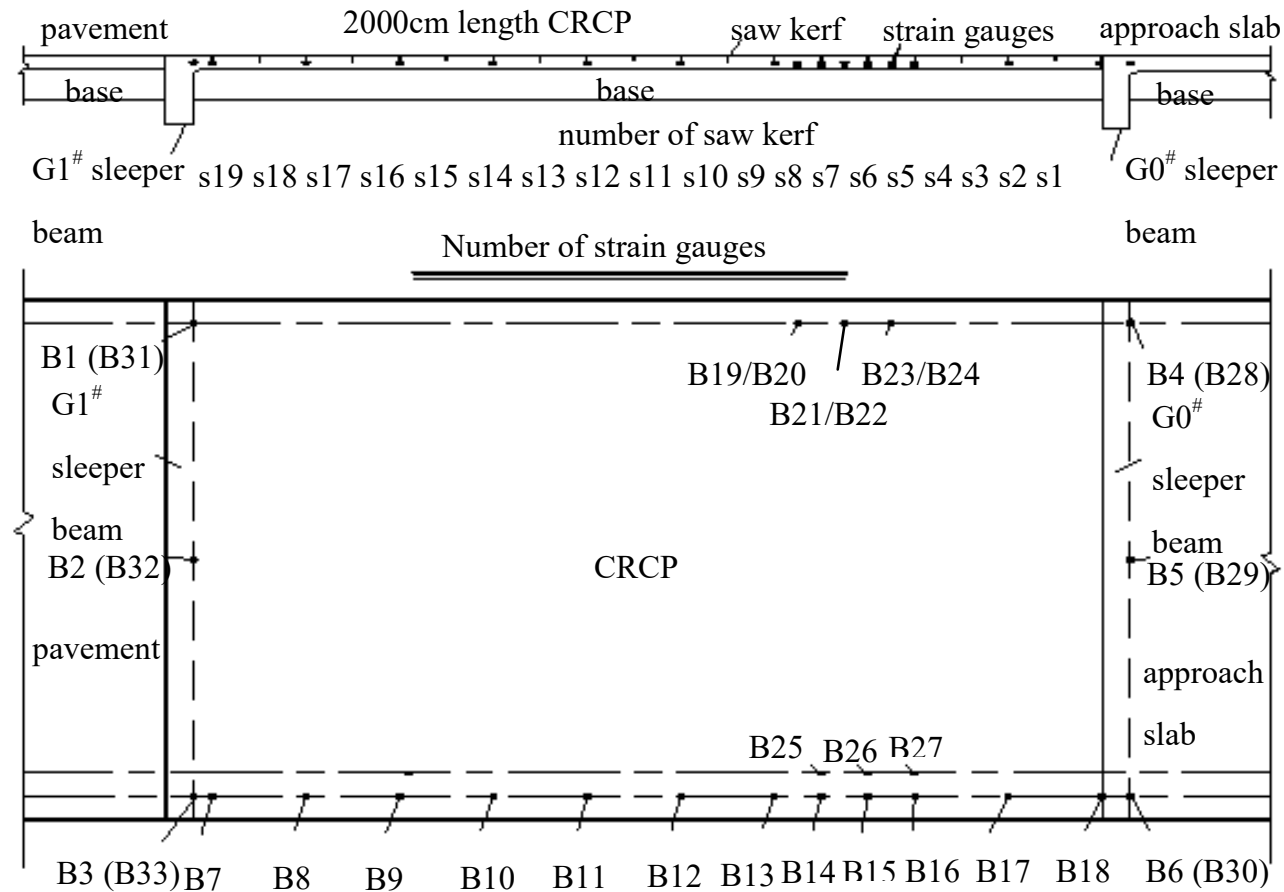

Fig. 8. Layout of the strain gauges of pavement

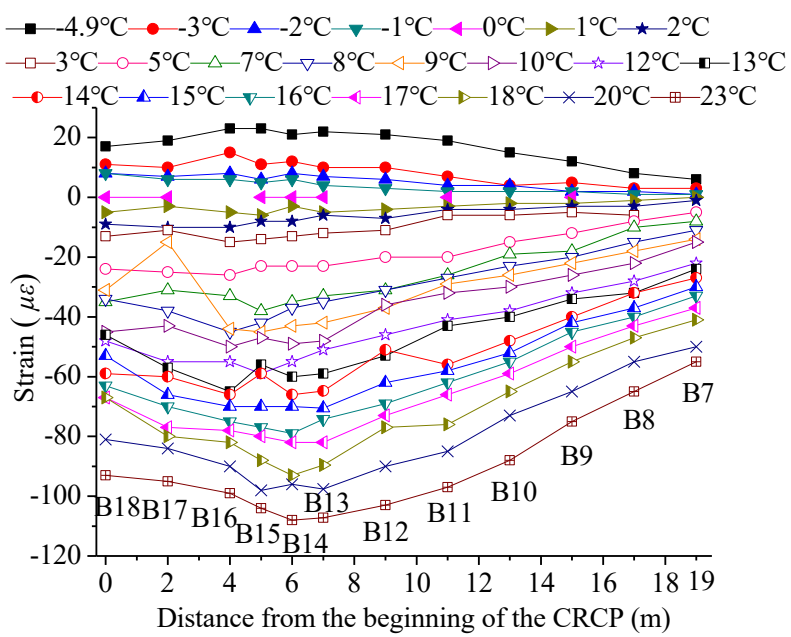

Fig. 9. Strain-temperature curves of pavement

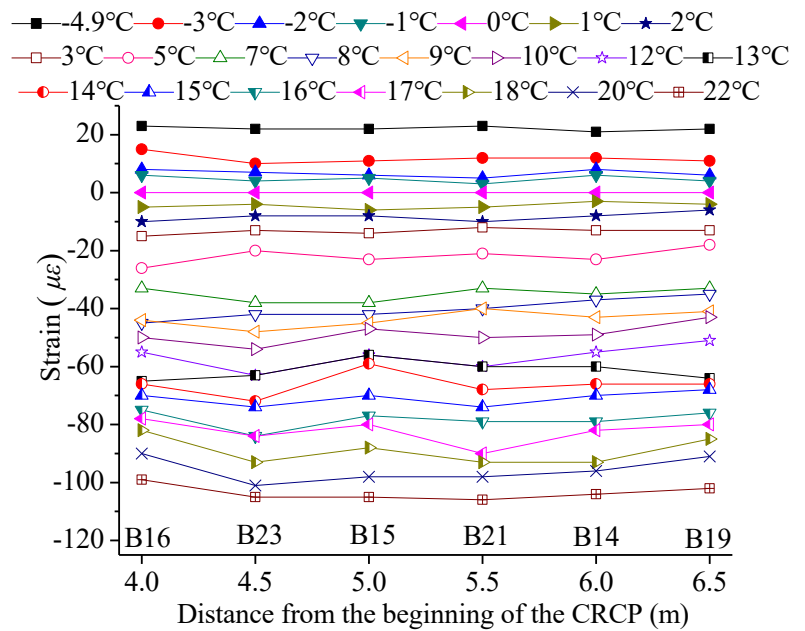

Fig. 10. Concrete strain at the middle of the CRCP between the saw kerf s4 to s7

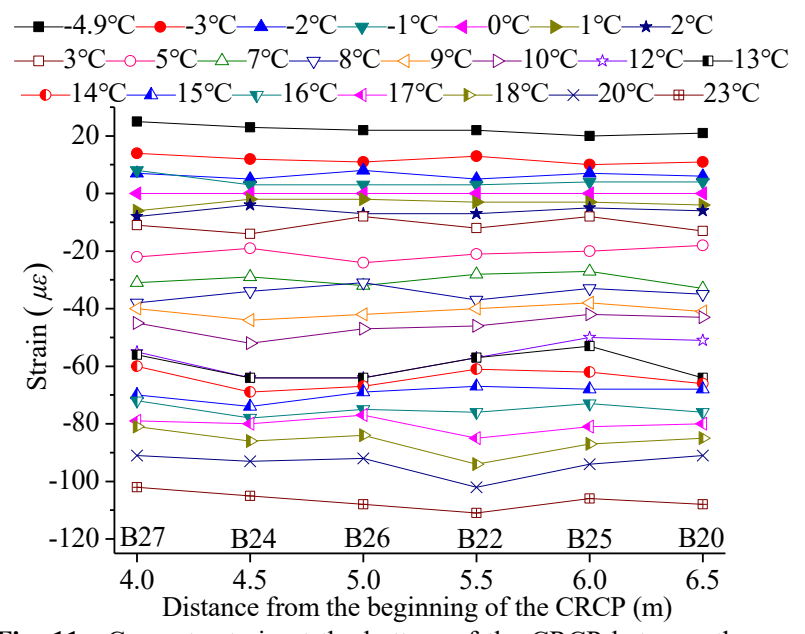

Fig. 11. Concrete strain at the bottom of the CRCP between the saw kerf $s 4$ to $\mathrm{s} 7$

The stress of the sleeper beam was surveyed. Three strain gauges were placed on the top of the $\mathrm{G} 0^{\#}$ sleeper beam (B4 to B6) near the $0^{\#}$ abutment, and the three were placed on the top of the $\mathrm{G} 1^{\#}$ sleeper beam (B1 to B3). As a control, six strain gauges, $\mathrm{B} 28$ to $\mathrm{B} 30$ and $\mathrm{B} 31$ to $\mathrm{B} 33$, were placed at the $\mathrm{G}^{\#}$ and $\mathrm{Gl}^{\#}$ sleeper beam near the $14^{\#}$ abutment, respectively (shown in Fig. 8). The results are shown in Fig. 12 and Fig. 13.

From Fig. 12 and Fig. 13, the maximum compression strain at the $\mathrm{Gl}^{\#}$ sleeper beam was $-58 \mu \varepsilon$ (B33). Accordingly, the compressive stress was $1.74 \mathrm{MPa}$. In the meantime, the maximum compression strain near the $\mathrm{G}^{\#}$ sleeper beam was $-31 \mu \varepsilon(\mathrm{B} 30)$, and the relative compressive stress was $0.93 \mathrm{MPa}$. Thus, the stress of the sleeper beam at the end of the CRCP $\left(\mathrm{Gl}^{\#}\right)$ is greater than that at the end of the slab beam $\left(\mathrm{GO}^{\#}\right)$. During the monitor period, given the small temperature drop, the maximum tensile strain was only $7 \mu \varepsilon$. The corresponding tensile stress was $0.21 \mathrm{MPa}$. The comparison of the sleeper strain tensile strain at the $0^{\#}$ abutment and $14^{\#}$ abutment, a similar distribution of the strain, is shown in Fig. 12 and Fig. 13. 


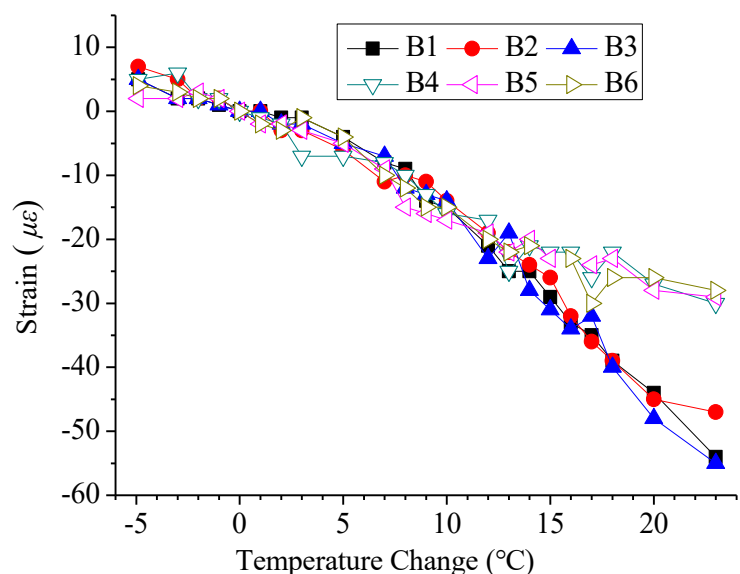

Fig. 12. Strain of sleeper beam near the $0^{\#}$ abutment

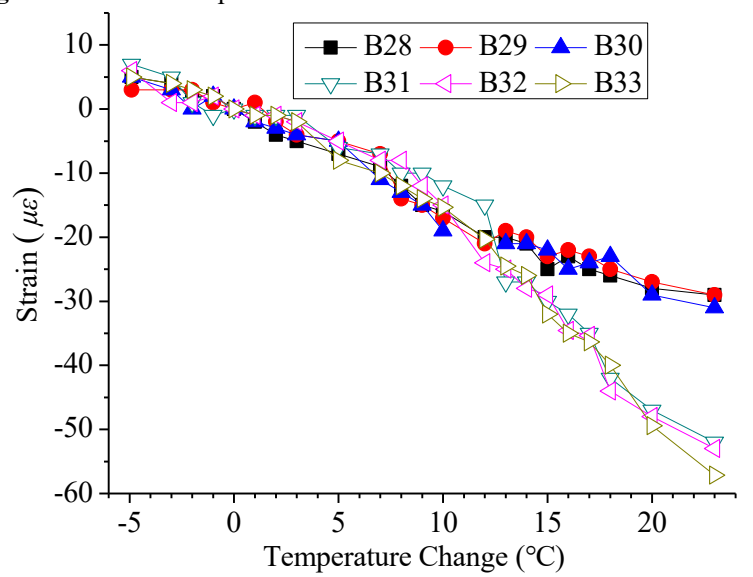

Eighteen soil pressure cells were used to investigate the backfill pressure caused by the temperature change. Twelve soil pressure cells were placed close to the south abutment ( $0^{\#}$ abutment), six of which were arranged on both sides of the $\mathrm{GO}^{\#}$ sleeper beam at the end of the approach slab (cells A7-A12). Cells A7 and A8 were installed near the central divider. Cells A9 and A10 were installed near the middle of the road, and Cells A11 and A12 were installed near the crash barrier. The other six were placed on both sides of $\mathrm{G}^{\#}$ sleeper beam (Cells A1-A6). As the control group, near the north abutment (14 ${ }^{\#}$ abutment), six soil pressure cells were placed at the inner side of $\mathrm{G}^{\#}$ and $\mathrm{G} 0^{\#}$ sleeper beams (Cells A13-A18) (shown in Fig. 14). The results of earth pressure are illustrated in Fig. 15 and Fig. 16. The data of the earth pressure were unstable because of the influence of the traffic vibration, and Cells of A3 and A10 were destroyed during the observation period because of the rolling of vehicles.

Fig. 15 and Fig. 16 show that, with a greater temperature change, the larger daily backfill pressure variation was consistent with the upper backfill soil being subjected to higher pressure attributable to bridge expansion. When the temperature dropped, the CRCP shrunk, and earth pressure sensors at the inner side were compressed, and the data of cells A2, A4, A6, A7, A9, and A11 were effective. As the temperature increased, the earth pressure sensors at the relative side were compressed, and the data of cells A2, A4, A6, A7, A9, and A11 were effective. The differences between soil pressure cells were not as significant as predicted. The earth pressure at the sleeper beam at the end of the CRCP ( $\mathrm{Gl}^{\#}$ sleeper beam) was slightly greater than that at the end of the approach slab $\left(\mathrm{G}^{\#}\right.$ sleeper beam $)$.

Fig. 13. Strain of sleeper beam near the $14^{\#}$ abutment

\subsection{Earth pressure}

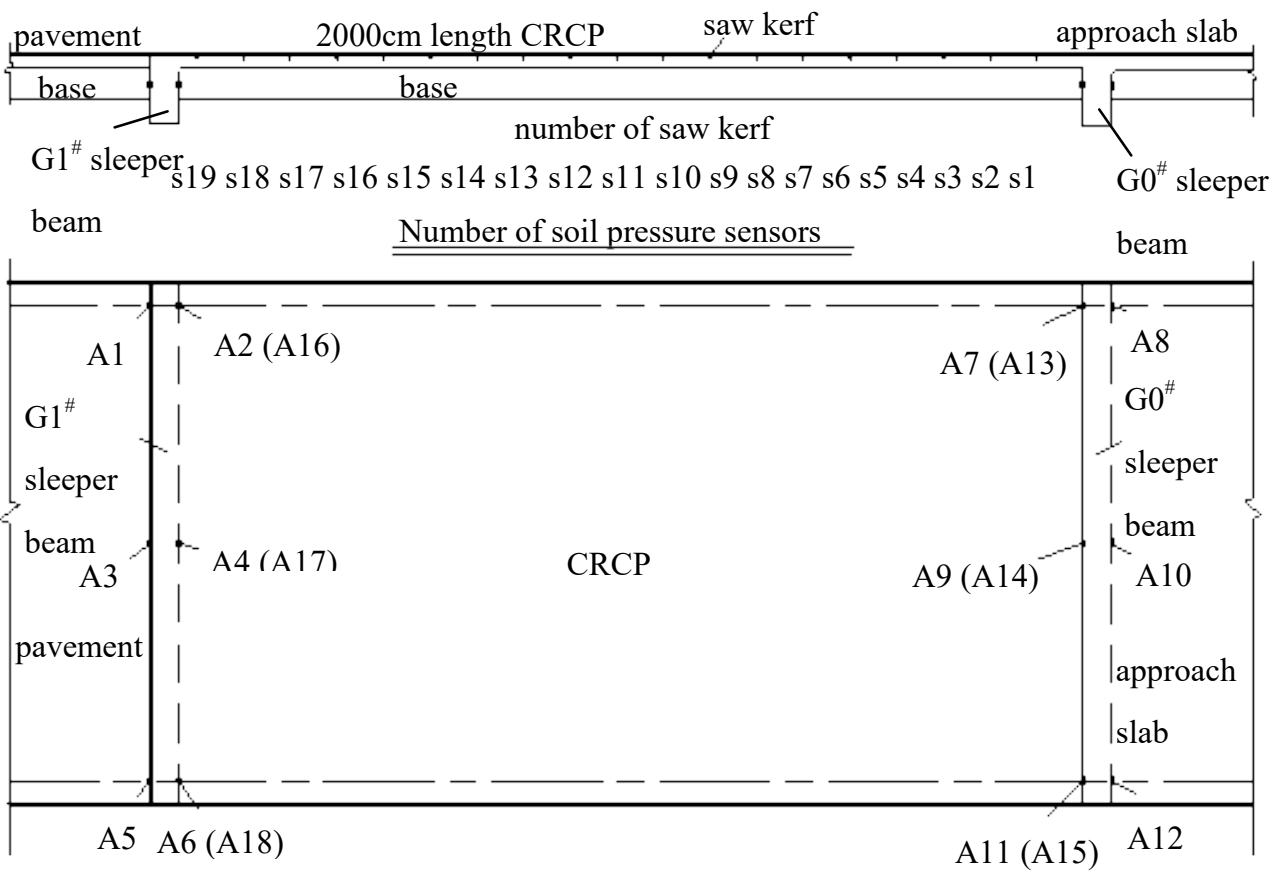

Fig. 14. Layout of earth pressure sensors (unit: $\mathrm{cm}$ ) 


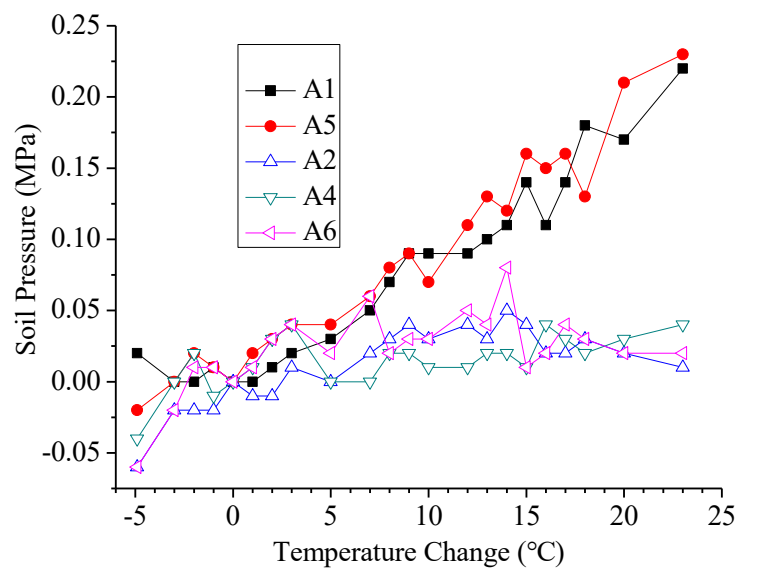

Fig. 15. Soil pressures around $\mathrm{G} 1^{\#}$ sleeper beam

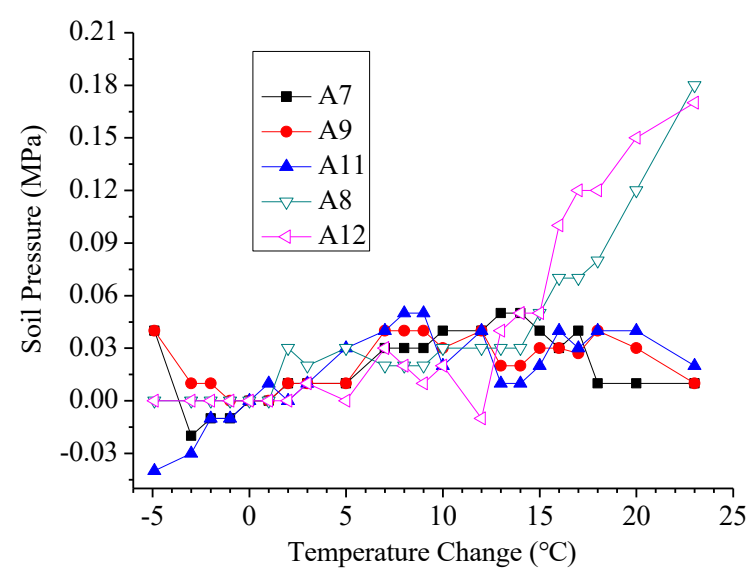

Fig. 16. Soil pressures around $\mathrm{G} 0^{\#}$ sleeper beam

\subsection{Longitudinal movement of girder}

The longitudinal movement of the main beam at the expansion joint of Dayankeng Bridge was measured. The expansion joint released the displacement, and the level indicators were welded on the crash barrier at each side of the expansion device at $5^{\#}$ pier and $9^{\#}$ pier separately. They were placed in a vertical plane along the centerline of the bridge at $200-\mathrm{mm}$ intervals. Additionally, displacements were measured at three different levels to gain more accurate results (Fig. 17). A negative value indicates a decrease in displacement, whereas a positive value indicates a displacement increase.

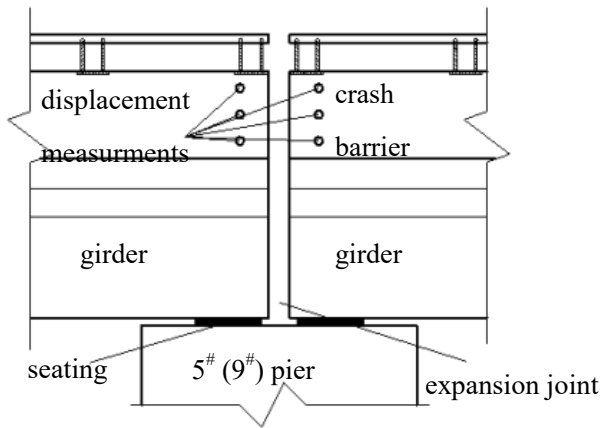

Fig. 17. Layout of the points of displacement observation

Fig. 18 shows the similar relative temperature displacements of $5^{\#}$ pier and $9^{\#}$ pier. With the increment of temperature, the bridge expands, and the relative displacement of the beam decreases. The greater increment of the temperature, the more the displacement decreases.
The maximum relative shortening was $-23.60 \mathrm{~mm}$ of the girder near $5^{\#}$ pier, upon a $23.0{ }^{\circ} \mathrm{C}$ temperature increment. Therefore, $59.8 \%$ of the temperature deformation was released through the expansion joint. Similarly, $59.7 \%$ of the temperature deformation was released through the expansion joint installed near $9^{\#}$ pier. In this case, approximately $40 \%$ of the thermal deformation was absorbed by the structure behind the abutment (especially $\mathrm{CRCP}$ ). The structure behind the abutment absorbed a $20 \%$ to $40 \%$ temperature deformation during the monitoring period. The greater the temperature difference, the greater the deformation was absorbed. In summary, because the CRCP absorbs partial of the temperature deformation of the girder, the bridge length of DEB can be longer, and the application area of the jointless bridge can be greatly expanded.

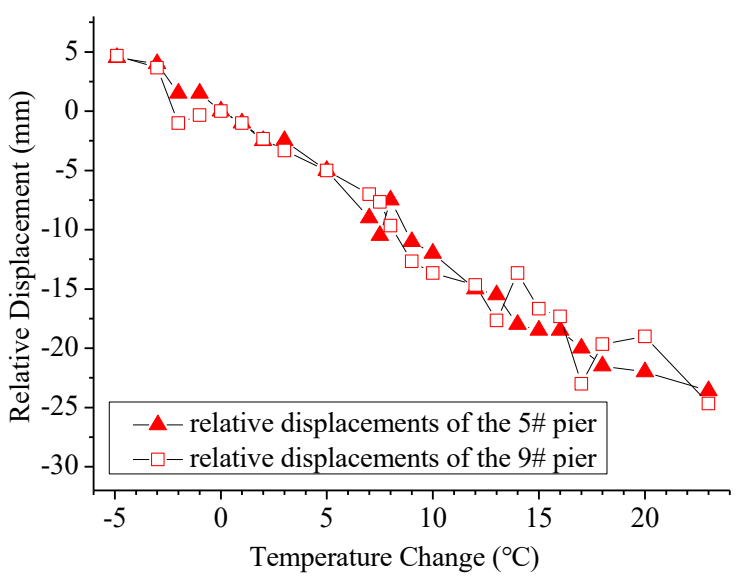

Fig. 18. Longitudinal displacement of the beam

\subsection{Visual inspection}

Routine examinations have been continued every 15 days to date. Through the most recent visual inspection, the expansion joint works well, and no visible cracking was observed on the structure's surface. Meanwhile, no sign of uneven settlement and damage at the end of the bridge was found, especially at the approach slab or the CRCP. Some recent photographs are shown in Fig. 19.

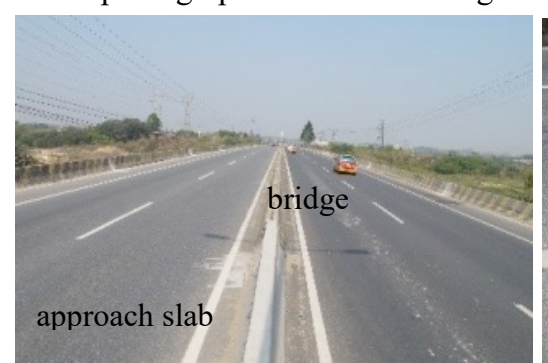

(a)

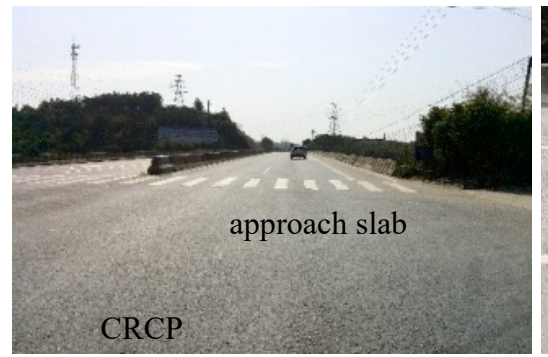

(c)

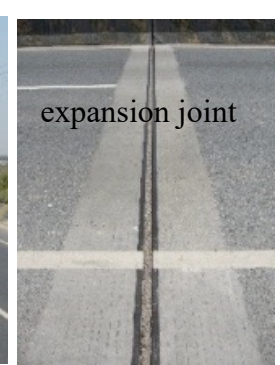

(b)

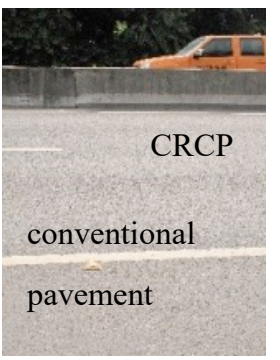

(d)
Fig. 19. Latest photograph of Dayankeng Bridge. (a) No obvious cracking in bridge and approach slab. (b) The expansion joint near $5^{\#}$ pier. (c) No obvious cracking in approach slab and CRCP. (d) The end of CRCP 


\subsection{Numerical studies}

The numerical calculation was performed by considering the maximum thermal loading (the temperature change was selected as $-4.9{ }^{\circ} \mathrm{C}$ ) to simulate the most unfavorable condition of Dayankeng Bridge. The results were compared with the monitoring data. The calculation results are shown in Fig. 20.

As seen from Fig. 20a, the maximum displacement of the main beam at $9^{\#}$ pier was $4.576 \mathrm{~mm}$, which was close to the measured data of $4.523 \mathrm{~mm}$ (as shown in Fig. 18), with an error of $1.2 \%$. Displacement of the main beam was reflected well by the FE model. It can also be represented from Fig. $20 \mathrm{a}$. The displacement of the sleeper beam at the end of the CRCP was only $0.5 \mathrm{~mm}$. Thus, the CRCP can be anchored effectively by the sleeper beam to prevent the temperature deformation from transmitting to the conventional pavement.

The maximum longitudinal normal stress of the CRCP appeared between the saw kerfs S4 to S5, and the maximum stress was $0.699 \mathrm{MPa}$ (in Fig. 20b), which was close to the test data of $0.69 \mathrm{MPa}$.

The segments between saw kerfs S4 to S5 were described carefully to observe the distribution of stress along the pavement height in more detail, as shown in Fig. 20c. The stress at the bottom of the pavement was greater than that of the top. The maximum stress at the bottom section was $0.688 \mathrm{MPa}$ and $0.503 \mathrm{MPa}$ at the top. It is caused by the friction between the CRCP and the base [32]. Thus, the reinforcement bar should be arranged at the bottom of the section as far as possible.

In Fig. 20d, the maximum longitudinal normal stress was $0.598 \mathrm{MPa}$ (at the bottom of the connection section between the approach slab and the CRCP). In comparison, the maximum normal stress at the connection section between the approach slab and the girder was $0.546 \mathrm{MPa}$. Accordingly, the relative maximum additional tensile stress caused by the structure behind the abutment was $0.137 \mathrm{MPa}$. The reconstruction of the abutment has little impact on the girder.
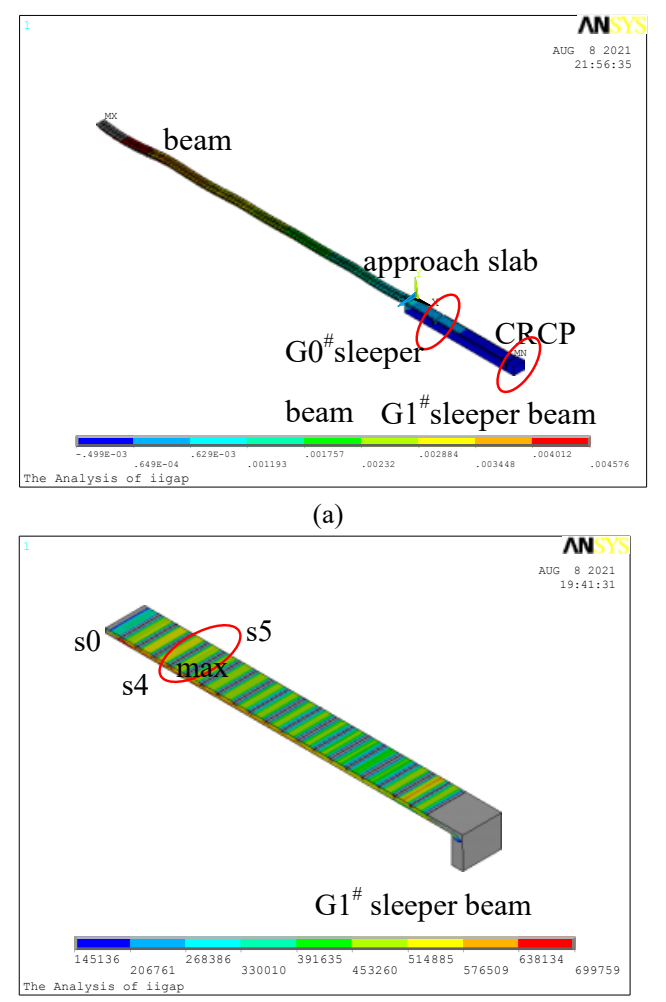

(b)

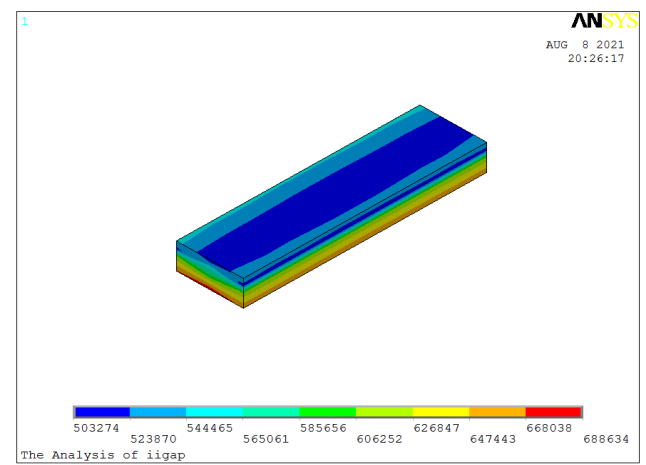

(c)

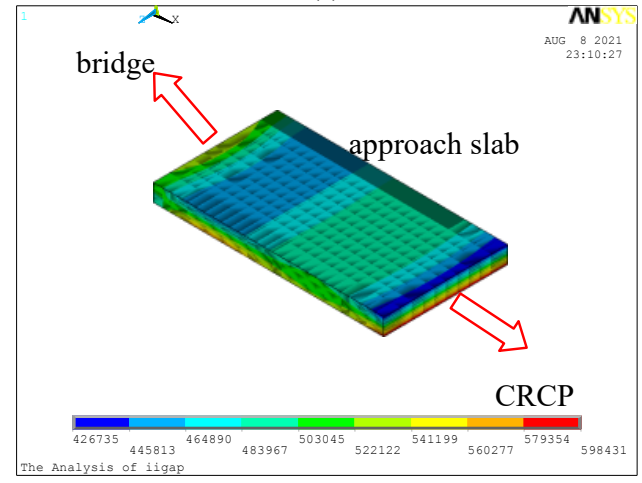

(d)

Fig. 20. Results of FE model. (a) Longitudinal displacement (Unit: $m$ ). (b) Longitudinal normal stress of CRCP (Unit: Pa). (c) Stress distribution of CRCP between saw kerf s4 to s5 (Unit: Pa). (d) Longitudinal normal stress of approach slab (Unit: $\mathrm{Pa}$ )

The number of earth pressure cells of Dayankeng Bridge was limited. Thus, describing the distribution of stress along the height around the sleeper beam was difficult. Therefore, the performance of the base around the sleeper beam was investigated by numerical analysis. Results are shown in Fig. 21.

Fig. 21 shows that the stress of the base around the sleeper beam decreases along the height from the bottom to the top gradually. At the position of the pressure cells (the height is $0.3 \mathrm{~m}$ ), the calculated stress was $0.05 \mathrm{MPa}$, which was close to the measured value. The maximum stress of the base was approximately $0.36 \mathrm{MPa}$, which occurred at the bottom of the sleeper beam near the CRCP. The phenomenon of stress concentration at the corner was evident because of the interaction of the sleeper beam and the base. Thus, it should be seriously considered in the design of the sleeper beam.

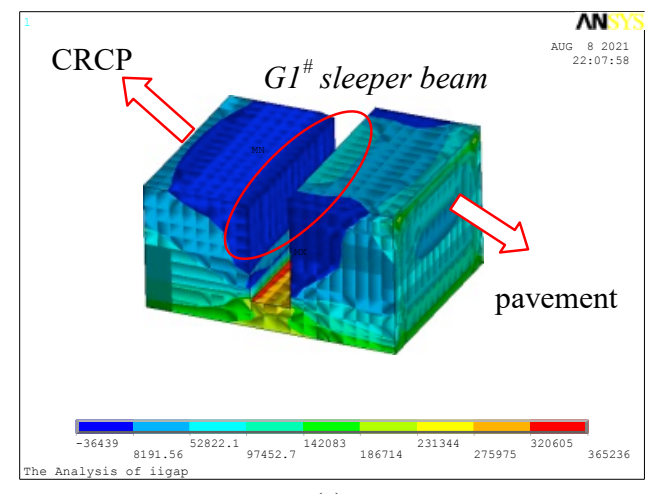

(a) 


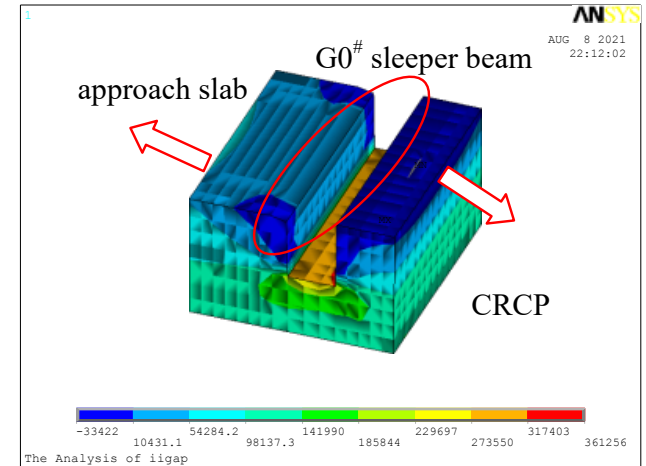

(b)

Fig. 21. Soil pressure around the sleeper beam. (a) Stress of the base around $\mathrm{Gl}^{\#}$ sleeper beam (Unit: Pa). (b) Stress of the base around $\mathrm{G} 0^{\#}$ sleeper beam (Unit: Pa)

\subsection{Different materials of the base}

Selecting appropriate base materials is important. By changing the resilient modulus (200 to $28000 \mathrm{MPa}$ [31]) to simulate the different types of base material and degrees of compaction, the parametric analysis was carried out. The results are shown in Table 2 .

With the increase of the resilient modulus of the materials of the base from $200 \mathrm{MPa}$ to $28000 \mathrm{MPa}$, the displacement of the end of the main beam decreased from $5.783 \mathrm{~mm}$ to $4.182 \mathrm{~mm}$, and the deformation absorbed by the structure behind abutment increased from $0 \%$ to $28 \%$ (in Table 2). The larger the base stiffness was, the more the deformation absorbed by the structure behind the abutment was. The additional force of the main beam, the maximum stress of the approach slab, and the CRCP were increased by the rise of the resilient modulus of the base. However, the influence on the performance of the girder and the CRCP by changing the material of the base was found to be limited.

Table 2. Calculation results of different base materials

\begin{tabular}{l|l|l|l|l}
\hline $\begin{array}{l}\text { Type of the } \\
\text { base } \\
\text { materials }\end{array}$ & $\begin{array}{l}\text { Resilient modulus } \\
(\mathbf{M P a})\end{array}$ & $\begin{array}{l}\text { Thermal displacement of the main beam } \\
(\mathbf{m m})\end{array}$ & $\begin{array}{l}\text { Maximum stress of main beam } \\
\mathbf{( M P a})\end{array}$ & $\begin{array}{l}\text { Maximum stress of CRCP } \\
\mathbf{( M P a})\end{array}$ \\
\hline Graded & & & & 0.601 \\
broken stone & 200 & 5.783 & 0.115 & 0.604 \\
& 400 & 5.721 & 0.116 & 0.608 \\
\hline Calcareous & 3000 & 5.650 & 0.117 & 0.635 \\
soil & 4000 & 5.320 & 0.124 & 0.645 \\
\hline Cement & 5000 & 5.210 & 0.126 & 0.656 \\
stabilized soil & 7000 & 5.100 & 0.128 & 0.672 \\
\hline Cement & 20000 & 4.990 & 0.130 & 0.693 \\
stabilized & 22000 & 4.576 & 0.135 & 0.699 \\
macadam & 25000 & 4.394 & 0.137 & 0.706 \\
& 28000 & 4.182 & 0.139 & 0.711 \\
\hline
\end{tabular}

\section{Conclusions}

The performance of SAB under the temperature effect was investigated. The long-term field monitoring, the numerical calculation, and the parameter analysis based on the instrumented bridge (Dayankeng Bridge) were performed by considering temperature change. The following conclusions could be drawn:

(1) Structure temperatures closely track the ambient temperature. Thus, ambient temperature can be employed to represent the structure temperature. During the whole monitoring period, the annual highest and lowest temperatures of the bridge experienced was $9.0{ }^{\circ} \mathrm{C}$, whereas the highest was $37.0{ }^{\circ} \mathrm{C}$, and the closure temperature was $9.0{ }^{\circ} \mathrm{C}$.

(2) The performance of the CRCP mainly depends on the temperature change. The test value of maximum tensile stress was $0.69 \mathrm{MPa}$, less than the tensile strength of $\mathrm{C} 30$ concrete. The maximum compressive stress was only 3.24 $\mathrm{MPa}$. Thus, no crack appeared during either under the coldest time or the warmest period. Generally speaking, the stress at the middle of the section was less than that of the bottom section of the pavement. Common concrete can be employed to meet the needs.

(3) The maximum thermal movement of the girder was $23.60 \mathrm{~mm}$, and approximately $40 \%$ of the temperature deformation was absorbed by the structure behind the abutment (especially the CRCP). The greater the temperature difference, the more of the beam deformation was absorbed by the structure. The $20 \%-40 \%$ of girder thermal displacement of SAB was absorbed by the CRCP. Thus, the length of the bridge can be longer, and the application area of the jointless bridge can be greatly expanded.

(4) Generally speaking, the earth pressure at the sleeper beam at the end of the CRCP is slightly greater than that at the end of the approach slab, and the stress along the height from the bottom to the top decreases gradually. The stress concentration at the corner is evident because of the interaction of the sleeper beam and the base. Therefore, the sleeper beam at the end of the CRCP should be considered emphatically in design.

(5) The different base types slightly influence SAB performance (such as the additional stress of the structure and the stress of the CRCP).

Thus, the temperature change was considered to investigate the performance of SAB in the study. However, these forces are influenced by many factors, such as vehicle vibration and creep. More influencing factors should be considered in future studies.

\section{Acknowledgements}

This work was supported by the Natural Science Project of Changsha City (kq2004088), the Scientific Research Program of the Department of Education of Hunan Province (18C0291), and the Youth Scientific Research Foundation of Central South University of Forestry and Technology (2018YC005 and 2016YJ031) and the Youth Scientific Research Foundation of Hunan Province (2020JJ5981).

This is an Open Access article distributed under the terms of the Creative Commons Attribution License. 


\section{References}

1. Stergios A. M., "Challenges and opportunities for the application of integral abutment bridges in earthquakes-prone areas: A review". Soil Dynamics and Earthquake Engineering, 135, 2020, pp.106183.

2. Byung H. C., Lorenz B. M., Churl S. L., Duy D. N., Tae H. g L., "Seismic performance evaluation of a fully integral concrete bridge with end-restraining abutments". Advances in Civil Engineering, 2019, 2019, pp.6873096.

3. Bao C. C., Yi Z. Z., Bruno B., “Jointless Bridges”. Beijing: China Communications Press Company Limited, China, 2019. pp.1-30

4. Hemanth K.T., Hota V.S. G., Jason M. Franco, "Performance evaluation of jointless bridge". Journal of Bridge Engineering, 7(5), 2002, pp.276-289.

5. Bao C. C., Cui F., Yi Z. Z., Bruno B., "The application status and development strategy of Jointless Bridges in China". Journal of China \& Foreign Highway, 38(1), 2018, pp.87-95.

6. Olli K., "Soil-structure interaction of long jointless bridges with integral abutment". Doctoral Dissertation of Tampere University of Technology, Finland, 2006, pp.1-18.

7. Tsinidis G. P., Maria M., "Response of integral abutment bridges under a sequence of thermal loading and seismic shaking". Earthquake and Structures, 16(1), 2019, pp.11-28.

8. Wooseok K. Jeffrey A. L., "Seven-year field monitoring of four integral abutment bridges". Journal of Performance of Constructed Facilities, 26(1), 2012, pp.54-64.

9. Hans P., Peter C., Milan V., "Monitoring of a Swedish integral abutment bridge". Journal of Structural Engineering International, 21(2), 2011, pp.175-180.

10. Jonathan K., Sreenivas A., "Integral abutment bridges: current practice in United States and Canada”, Journal of Performance of Constructed Facilities, 14(3), 2000, pp.104-111.

11. Highway Agency, "Design manual for roads and bridges Volume1 Highway structures: approval procedures and general design Section 3 General design Part 12 the design of integral bridges". England: Stationery Office, England, 2003, pp.1-150.

12. Yi B. Z., "Study on single expansion joint bridge applicable for large or medium bridge". Doctoral Dissertation of Hunan University, China, 2016, pp.1-70.

13. Xu D. S,, Xue F. Z., Xiao Q. J., Zhi X. C., “Temperature effect of innovative semi-integral abutment jointless bridge with ground beam". China Journal of Highway and Transport, 23(1), 2010, pp.43-48.

14. Yi B. Z., Xu D. S., Jing M., Yong C. M., "Temperature Effect for Reinforced Approach Pavement of Single Expansion Joint Bridge". China Journal of Highway and Transport, 27(5), 2014, pp.131-140.

15. Yi B. Z., Xu D. S., "Study on temperature effects of single expansion joint bridge". Engineering Science, 14(10), 2012, pp.103-112.

16. Xue F. Z., Kai L. L., Yi B. Z., Heng L. Y., “Tensile performance of SHCC road-bridge link slabs in fully jointless bridges". Advances in Civil Engineering, 2021, 2021, pp.6643643.

17. Abdel-Fattah M. T., Abdel-Fattah T. T., "Behavior of integral frame abutment bridge due to cyclic thermal loading: nonlinear finite-element analysis". Journal of Bridge Engineering, 24(5), 2019, pp.04019031.
18. Nassr N. S., Mohsen A. I., "Calibration and parametric investigation of integral abutment bridges", Engineering Structures, 227, 2021, pp.111381.

19. Bhavesh T., Ashwin H., "Finite element analysis of integral bridge using Midas", Compliance Engineering Journal, 11(3), 2020, pp.08983577.

20. Sigdel L., AI-Qarawi A., C. Leo, S. L., P. Hu, V. Doan, "Response of approach to integral abutment bridge under cyclic thermal movement", Advances in Geotechnical Engineering \& Geoenvironmental Engineering, 2021, doi: 10.1007/978-3-03080142-7 1.

21. D.S. L., C.J. Leo, Alqarawi A.S., "A study on the effects of abutment cyclic movements on the approach of integral abutment bridges". Australian Geomechanics, 5(2), 2016, pp.1-13.

22. Hao L., Jie H., Robert L. P., "Mitigation of seasonal temperature change-induced problems with integral bridge abutments using EPS foam and geogrid". Geotextiles and Geomembranes, 49(5), 2021, pp.1380-1392.

23. A. S. A., C. J. Leo, D.S. L., S.D. E., "A study on the effect of abutment cyclic movements on the approach of integral abutment bridges". Australian Geomechanics, 51(2), 2016, pp.08189110.

24. Moon S. N., Young H. P., "Relationship between earth pressure and thermally induced movement of integral abutments". Journal of Performance of Constructed Facilities, 29(4), 2015, pp.04014093.

25. S. A. H., A. J. V., "Nine-year field-monitoring data from an integral-abutment bridge", Geotechnical Special Publication, (299), 2018, pp.101-111.

26. Fu Y. H., Han L. C., Rui D., Yu L. S., "Experimental study of single pile-soil interaction under horizontal low-cycle reciprocating displacement", Rock and Soil Mechanics, 41(5), 2020, pp.16251634.

27. Fu Y. H., Yu L. S., Yi Z. Z., Xiao Y. L., Bao C. C., "Pseudo-static low cycle test on the interaction of predrilled-hole micro-pile and soil in integral abutment jointless bridges", Journal of Fuzhou University, 48(3), 2020, pp.368-374

28. Cui F., Zheng H. F., Yi Z. Z., Bao C. C., "Study on micropile under approach slab and soil interaction in jointless bridge". Journal of Fuzhou University, 45(2), 2017, pp.179-184

29. Yu F. T,, Jun Q. X. Pei Q., Bruno B., Bao C. C., "Experimental study on the friction coefficient of the sliding material of the platetype approach slab for jointless bridges". In: the 26th National Academic Conference on Structural Engineering, Changsha, China: IE\&EM, 2017, pp.514-519.

30. China Merchants ChongQing Communications Technology Research \& Design institute CO. LTO, "Specifications for Seismic Design of Highway Bridges (JTG/T 2231-01-2020)". Beijing: China Communications Press Company Limited, 2020, pp.71-90.

31. Road \& Bridge international CO., LTD, "Specifications for Design of Highway Asphalt Pavement (JTG D50-2017)", Beijing: China Communications Press Company Limited, 2017, pp.12-22.

32. Xing F. L., "Temperature stress analysis of concrete structure". Beijing: China Communications Press Company Limited, 1991, pp.195-215. 